\title{
Plant tissue tests for predicting nitrogen fertilizer requirements in spring wheat
}

\begin{abstract}
JARI PELTONEN
Peltonen, J. 1992. Plant tissue tests for predicting nitrogen fertilizer requirements in spring wheat. Agric. Sci. Finl. 1: 509-517 (Univ. Helsinki, Dept. Plant Production, SF-00710 Helsinki, Finland.)

Application of nitrogen $(\mathrm{N})$ at sowing (basal $\mathrm{N}$ ) alone is not always adequate for maximum yield and quality formation in wheat (Triticum aestivum L.). Because uptake and utilization of $\mathrm{N}$ by the plant is influenced by many environmental and varietal factors, supplementary $\mathrm{N}$ may be needed during the growing season, too. Additional $\mathrm{N}$ can be applied at particular stages of the plant's development (phenology) to produce the best result from its use.

The applicability of plant tissue $\mathrm{N}$ concentration as a diagnostic tool for measuring the $\mathrm{N}$ status of a wheat stand to guide economical use of additional $\mathrm{N}$ application was reviewed here. On the basis of grain protein concentration data, growers producing spring wheat with consistently low protein concentration are advised to pursue a more vigorous and better planned $\mathrm{N}$ fertilization programme in their crops. Plant tissue $\mathrm{N}$ testing provides a useful method for the producer to annually optimize wheat grain yield and grain protein concentration. Knowledge of both these 'critical components' as determined by pre-harvest $\mathrm{N}$ levels of plant tissue and post-harvest grain protein concentration can be utilized for making both basal and supplemental $\mathrm{N}$ fertilizer recommendations.
\end{abstract}

Key words: spring wheat (Triticum aestivum $\mathrm{L}$.), critical tissue N, grain yield, protein content

\section{Introduction}

The present recommendation by the leading fertilizer supplier in Finland for basal $\mathrm{N}$ fertilizer application for spring wheat in southern Finland varies from 110 to $140 \mathrm{~kg} \mathrm{~N}^{-1}$ depending on soil type and previous cropping. These recommendations provide the framework on which the grower must base the nutritional requirement of his crop. However, precise determination of the optimum amount of $\mathrm{N}$ to apply is not easy, because $\mathrm{N}$ fertilizer requirements are influenced by many factors: the total demand of a crop for $\mathrm{N}$, mineralized $\mathrm{N}$ present in the soil at the time of $\mathrm{N}$ application, and $\mathrm{N}$ mine- ralization during the growing season (WEHRMANN et al. 1982). Therefore, fertilizer recommendations are generalizations, which are only applicable in growing seasons and on farms where growing conditions coincide with the mean values of the field trials used as the basis for the recommendation. In actual fact, yield responses of spring wheat to $\mathrm{N}$ fertilization vary widely within one region, between regions, and from one year to another (HEIKKILÄ 1980). According to the author, the economical (90-180 $\mathrm{kg} \mathrm{N} \mathrm{ha}^{-1}$ ) as well as biological (120-200 $\left.\mathrm{kg} \mathrm{N} \mathrm{ha}^{-1}\right)$ optima for basal $\mathrm{N}$ application rate vary greatly. More precise recommendation may be possible by developing a proper scientific 
foundation as to timing of $\mathrm{N}$ for a crop.

Nitrogen uptake efficiency by plants is strongly regulated by environmental factors such as soil and air temperature (SPIERTZ 1977, LAWLOR et al. 1988), drought (which reduces fertilizer solubility and stresses the plant), or excessive rains (which may cause $\mathrm{N}$ leaching and water logging) (PELtoNEN et al. 1990), and management practices such as irrigation (ELONEN et al. 1975), as well as time, form and rate of $\mathrm{N}$ fertilizer applied (FAJERSSON 1961, RAININKo 1966, JAAKKOLA 1978, SvensSON and LindaHL 1989). Therefore, soil testing for establishing the $\mathrm{N}$ fertilizer recommendations made on the basis of short term $\mathrm{N}$ mineralization measurements have been unreliable (SCHARPF and WEHRMANN 1976, STANFORD 1982). Adverse sowing conditions such as heavy rain can lead to denitrification losses of $\mathrm{N}$ fertilizer (ESALA 1991) and lead to the need for adjustment of $\mathrm{N}$ later. There are also varietal differences in $\mathrm{N}$ uptake efficiency (SETH et al. 1960, Mikesell and PAulsen 1971, NOAMAN and TAYLOR 1990). The situation may be affected by leaf shading, which becomes more significant at high plant population densities leading to translocation of $\mathrm{N}$ from shaded leaves (CAMPBEll and ReAD 1968, Willey and Holliday 1971, BREMNER 1972). It has also been shown that prolonged root activity and leaf duration positively affect $\mathrm{N}$ accumulation into the grain (SPIERTZ and Ellen 1978, Herzog and Stamp 1983). Because the utilization of $\mathrm{N}$ by a plant is controlled by so many factors, supplemental $\mathrm{N}$ may be needed if basal $\mathrm{N}$ application at sowing is insufficient or not optimal for wheat growth.

In conclusion, optimal timing of $\mathrm{N}$ to reduce annual variation in grain yield and quality in wheat requires a more detailed knowledge of $\mathrm{N}$ requirements of the wheat crop during its growth and development, and hence a way of accurately assessing the total $\mathrm{N}$ demand of the crop must be available. This review article examined whether the technique of tissue $\mathrm{N}$ testing can provide a useful method for optimizing wheat grain yields and protein concentration.

\section{Relationship between tissue nitrogen concentration and crop yield}

Crop yield and quality of yield are determined by internal and external growth factors. The former are governed by genetic factors, and the latter by environmental factors (SIMAN 1974). Nutrient supply is an external factor that can be regulated quite easily. The increased $\mathrm{N}$ concentration increases total plant dry-mass, leaf area of main shoots slightly but of tillers greatly (LAWLOR et al. 1988). The photosynthesis per unit area increases with increasing $\mathrm{N}$ supply (LAWLOR et al. 1989). Cool conditions increase the root dry-mass, the root to shoot ratio and the $\mathrm{N}$ content in plant dry-mass (LAWLOR et al. 1988). All this relies, however, upon the interactive effects of weather and soil factors, and may be modified by the occurrence of pest, weeds and disease control (WEHRMANN et al. 1982, Hagrove et al. 1983, Needham 1983, Peltonen and KARJALAINEN 1992).

Plant analysis can be used to determine a crop's nutritional status at various developmental stages to guide the fertilizer programme or as a means of obtaining valuable economic information on the nutrient availability in soils. BENZIAN and LANE (1981) have indicated that there are four general types of curves of yield responses to $\mathrm{N}$ fertilizer application: positive linear, convex without a maximum, convex with a maximum, and negative linear. The authors concluded that as a rule the grain protein concentration of wheat increased linearly, whereas many of the grain yield curves reached a maximum and then declined with further additions of $\mathrm{N}$. Therefore the use of $\mathrm{N}$ fertilization in excess of that needed for a maximum yield only seemed to result in increased grain protein concentration (BENZIAN and LANE 1981). The nitrogen concentration of the wheat plant decreases during growth although $\mathrm{N}$ uptake continues until maturity (SIMAN 1974, ANGUS and Moncur 1985, HARPER et al. 1987, Peltonen 1992). These authors have shown that the $\mathrm{N}$ concentration decreased from $50-60 \mathrm{~g}$ $\mathrm{kg}^{-1}$ at floral initiation to $20-30 \mathrm{~g} \mathrm{~kg}^{-1}$ at anthesis.

The factors contributing to variation in plant tis- 
sue $\mathrm{N}$ concentration can be classified into variation (a) in plant developmental stages, and variation (b) in N supply (SIMAN 1974). The variation (a) is genetically controlled and its presence is revealed by the downward trend in $\mathrm{N}$ concentration as the plant matures irrespective of the $\mathrm{N}$ supply. The variation (b) caused by $\mathrm{N}$ supply is related to changes in growth which depend on the $\mathrm{N}$ available in soil. It is necessary, therefore, to separate the variation as a result of the developmental stage from that dependent on the $\mathrm{N}$ supply. Variation (a) can be partly eliminated by sampling at identical developmental stages, whereby the variation in the tissue $\mathrm{N}$ concentration is only dependent on the $\mathrm{N}$ supply (SIMAN 1974). In contrast, sampling based only on a fixed dry matter weight level (DMwlevel), as suggested by MøLLER NIELSEN and FrIISNiELSEN (1976), is not sufficiently accurate to explain the variation in $\mathrm{N}$ concentration described above (PELTONEN 1992).

For the interpretation of internal nutrient concentration, UlRICH and HILlS (1967) presented a concept of the growth (as yield response) and nutrient concentration curve. According to the authors, the nutrient concentration values can be divided into zones related to their impact on yield. These zones in the calibration curve are as follows: (i) the zone of deficiency, i.e. the growth increases sharply but there is little change in the concentration of the nutrient, (ii) the zone of transition, i.e. both the nutrient concentration and growth increase, and (iii) the zone of adequacy, when the nutrient concentration increases, but there are no more changes in growth. STEENBJERG (1951) found that plants which were extremely deficient in one nutrient had a higher concentration of this nutrient at maturity than plants that were less deficient in the same nutrient. When small amounts of this nutrient were supplied, it stimulated the vegetative growth to such an extent that the increased yield production caused decreases in the nutrient concentration. It is noteworthy that this "Steenbjerg effect" was also observed in the work of MølLeR NIELSEN and FrIIS-NIELSEN (1976) in the mature crop, but not in the young plants with increasing $\mathrm{N}$ applications.

\section{Selection of plant part and methods for plant analyses}

Four parameters for testing plant tissue have been suggested as indicators of $\mathrm{N}$ fertilizer requirements for wheat: (i) stem nitrate nitrogen $\left(\mathrm{NO}_{3}-\mathrm{N}\right)$ concentration (GARDNER and JACKSON 1976, PAPASTYlianou and PUCKRIDGe 1981), (ii) whole plant N concentration (ENGEL and ZUBRISKI 1982, Roth et al. 1989, VAUGHAN et al. 1990a), (iii) leaf $\mathrm{N}$ concentration (VAUGHAN et al. 1990a), and (iv) crop $\mathrm{N}$ uptake (Roth et al. 1989). The stem $\mathrm{NO}_{3}-\mathrm{N}$ test has been proposed as a satisfactory method of predicting $\mathrm{N}$ deficiency in wheat (PAPASTYLIANOU and PuCKridge 1981, WehrmanN et al. 1982), but some researchers have reported that critical $\mathrm{NO}_{3}-\mathrm{N}$ levels can vary greatly from site to site (BERINGER and Hess 1979, Roth et al. 1989, VAughan et al. 1990a) and can change rapidly over time (RoTH et al. 1989). Therefore, more samples were needed to achieve a confidence level of accuracy for the $\mathrm{NO}_{3}$ $\mathrm{N}$ test than for testing the whole plant $\mathrm{N}$ concentration (RoTH et al. 1989). Total N concentration can be misleading in some cases because dry matter yield can either be low or high at the same level of $\mathrm{N}$ applied to crop if the amount of $\mathrm{N}$ taken up and the amount of dry-mass produced vary in such a way that the concentration of $\mathrm{N}$ in tissue remains similar (SIMAN 1974). Critical N uptake levels are too variable to be used alone for monitoring a crop's N status (BERINGER and Hess 1979, ROTH et al. 1989, Peltonen 1992). The critical level of $\mathrm{N}$ uptake can be, however, used as an indicator of whether the high $\mathrm{N}$ concentration is due to the low dry-mass production or high $\mathrm{N}$ uptake level of the wheat plant (SIMAN 1974, RoTH et al. 1989).

According to ALDRICH (1973), there are two general analytical methods for plant analyses: (i) total or quantitative (total chemical analysis or spectrographic analysis) and (ii) relative quantity or semiquantitative (rapid tissue tests). The total or quantitative analysis measures both the elements that have already been incorporated into plant tissue and those that are still present as soluble constituents of the plant sap. The determination may be 
made by the Kjeldahl method or by chemical separation followed by weighing the constituents being determined. Other techniques measure the quantity of an element by the amount of light emitted following excitation in an appropriate manner by heat and high voltage (emission spectrograph) or by Xray bombardment (X-ray spectrograph). The semiquantitative analysis, e.g. the rapid $\mathrm{NO}_{3}-\mathrm{N}$ tissue tests (Wehrmann et al. 1982, Scaife and Stevens 1983, NITSCH and VARIS 1991), measures the unassimilated, soluble contents of the plant sap (ALDRICH 1973). An advantage of "rapid tests" is that they can be used in the field, or when laboratory facilities for total chemical analyses are not readily available.

\section{Estimation of nitrogen utilization by wheat plant}

Analyzing soil for inorganic $\mathrm{N}\left(\mathrm{NO}_{3}-\mathrm{N}+\mathrm{NH}_{4}-\mathrm{N}\right)$ (WeHRMANN and ScharpF 1979, WeHrmann et al. 1982) provides a valuable means of revealing the amount of $\mathrm{N}$ available for plant growth. However, the amount of available $\mathrm{N}$ present in the soil depends on soil type, the cultivation system, preceding crop, straw disposal, crop species or even the cultivar cultivated, pests, weeds and diseases, and soil water supply (HARGROve et al. 1983, Needham 1983, Peltonen and Karjalainen 1992).

If available $\mathrm{N}$ is a limiting factor, protein concentration often becomes more a function of total grain yield than of the genetic potential of a particular cultivar to produce protein. In this situation, the highest yielding cultivars will suffer the greatest reductions in protein even if they have genetic potential for protein production (FowLER and de la ROCHE 1984). The analysis of grain protein has been successfully used in Colorado and North Dakota to evaluate post-harvest previous $\mathrm{N}$ management practices and to guide future $\mathrm{N}$ fertilizer recommendations (Goos 1984). Previously Goos et al. (1982), Goos (1984) and VAughan et al. (1990b) indicated that simple Cate-Nelson models (CAte and Nelson 1971, Nelson and Andersen
1977) are sufficient for the calibration of critical levels of $\mathrm{N}$ in the soil and $\mathrm{N}$ in the plant. In CateNelson model II the data for critical $\mathrm{N}$ concentration are interpreted as $\mathrm{N}$ responsive or $\mathrm{N}$ nonresponsive categories in terms of grain yield and/or grain protein concentration. In contrast, CateNelson model III separates the data into three groups: $\mathrm{N}$ fertilizer responsive, transitional, and non-responsive data.

On the basis of grain yield and grain protein data collected during 1968 - 1988, Cate-Nelson model II predicted that if the grain protein concentration is less than 11.2 percent in southern Finland, yield losses would be associated with $\mathrm{N}$ deficiency (Figure 1). On the basis of these data, growers producing spring wheat with consistently low protein concentrations are advised to pursue a more vigorous and better planned $\mathrm{N}$ fertilization programme in their crops. In years of drought, yields are usually low and the protein content will generally be high (KonTturi 1979). However, in such years, the $\mathrm{N}$ requirement for maximum yield will also be lower. Analysis of the critical levels of grain protein has been found to be applicable in both good and poor years (Goos 1984). However, the author pointed out that there have been situations where the model has not been validated. For example, where there is early season $\mathrm{N}$ deficiency but $\mathrm{N}$ is available through root uptake later, the often observed high protein concentration in the grain is a result of yield loss due to $\mathrm{N}$ deficiency. Such situations have been rare in the data of PELTONEN et al. (1990) concerning the yields in 1968-1988 in southern Finland.

\section{Tissue nitrogen levels related to grain yield and grain protein concentration}

Plant tissue analysis can provide an effective means of monitoring the nutritional status of a crop at an advanced developmental stage. If critical tissue $\mathrm{N}$ concentrations are known, potential deficiencies can be identified before visual symptoms appear. Also the sufficiency of $\mathrm{N}$ in tissue can be monitored. If $\mathrm{N}$ deficiencies are identified early enough, additional $\mathrm{N}$ can be applied to the crop before yield 


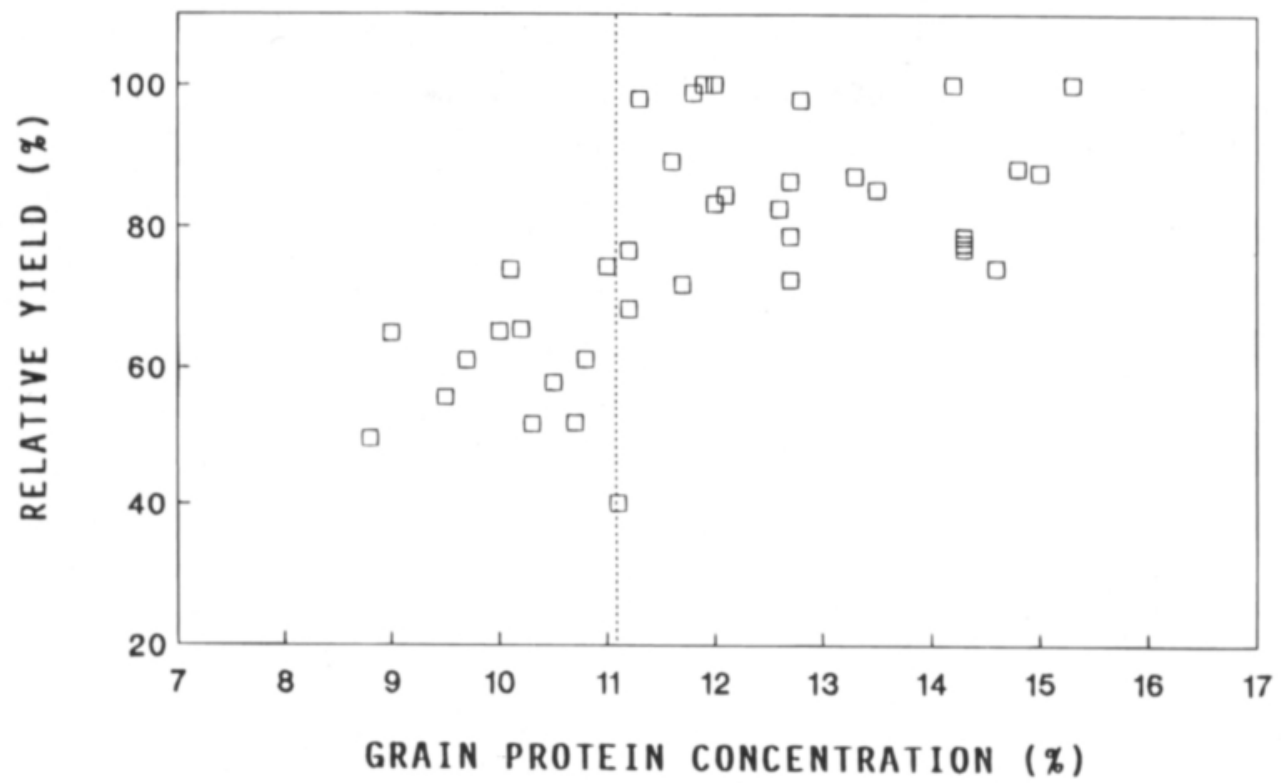

Fig. 1. Relative yields of spring wheat as related to grain protein concentration in southern Finland (after PELTONEN 1992).

Table 1. Critical $\mathrm{N}$ values related to grain yield in spring wheat reported in the literature.

\begin{tabular}{|c|c|c|c|c|c|}
\hline $\begin{array}{l}\text { Growth } \\
\text { stage }\end{array}$ & $\begin{array}{l}\text { Plant } \\
\text { part }\end{array}$ & $\mathrm{N}$ analyzed & $\begin{array}{l}\text { Critical } \\
\text { value } \\
\left(\mathrm{g} \mathrm{kg}^{-1}\right)\end{array}$ & Country & Reference \\
\hline Feekes 10.5 & Whole plant & Total N & $18-26$ & USA & ENGEL and ZUBRISKI (1982) \\
\hline Feekes 10.5 & Top two leaves & Total N & $36-45$ & USA & ENGEL and ZUBRISKI (1982) \\
\hline Feekes 10.5 & Flag leaf & Total N & $<35$ & USA & HAGROVE et al. (1983) \\
\hline Feekes $9-10$ & Whole plant & Total N & $24-35$ & USA & ENGEL and ZUBRISKI (1982) \\
\hline Feekes 9-10 & Top two leaves & Total N & $41-50$ & USA & ENGEL and ZUBRISKI (1982) \\
\hline Feekes $9-10^{a}$ & Whole plant & Total N & $<28$ & Finland & PELTONEN (1992) \\
\hline Feekes $9-10^{a}$ & Leaves & Total N & $30-38$ & Finland & PELTONEN (1992) \\
\hline Feekes 7 & Whole plant & Total N & $19-27$ & USA & VAUGHAN et al. (1990a) \\
\hline Feekes 7 & Leaves & Total N & $34-41$ & USA & VAUGHAN et al. (1990a) \\
\hline Feekes 5-6 & Whole plant & Total N & $42-51$ & USA & ENGEL and ZUBRISKI (1982) \\
\hline Feekes 5 & Whole plant & Total N & $25-33$ & USA & VAUGHAN et al. (1990a) \\
\hline Feekes 5 & Leaves & Total N & $34-38$ & USA & VAUGHAN et al. (1990a) \\
\hline Feekes $1-2^{a}$ & Whole plant & Total N & $<43$ & Finland & Peltonen (1992) \\
\hline Feekes 10 & Stems & NO3-N & $3-9$ & USA & GARNER and JACKSON (1976) \\
\hline Feekes 7-8 & Stems & NO3-N & $5-10$ & USA & GARNER and JACKSON (1976) \\
\hline Feekes 3-4 & Stems & NO3-N & $6-10$ & Australia & PAPASTYLIANOU (1984) \\
\hline Feekes 3-4 & Stems & NO3-N & $7-12$ & USA & GARNER and JACKSON (1976) \\
\hline
\end{tabular}

$\mathrm{a}=$ the apex developmental stages: early double-ridge stage and stage when stigmatic branches of carpel have formed have been estimated to correspond to the Feekes scale. 
and quality are reduced. A summary of critical $\mathrm{N}$ levels in wheat tissue at different growth stages has been presented in Table 1. Previously Vaughan et al. (1990a) concluded that the observed differences between critical $\mathrm{N}$ levels could be due to the differences in the growing conditions in varying geographical regions and/or wheat classes.

The study of SPRATT (1974) indicated that critical $\mathrm{NO}_{3}-\mathrm{N}$ concentration of $300 \mathrm{ppm}$ in dry-matter (DM) of above-ground parts of plant at anthesis was required for optimum grain protein concentration in grains. Peltonen (1992), in turn, showed that differences in $\mathrm{R}^{2}$ in tissue $\mathrm{N}$ content between different plant parts at anthesis were insufficient to justify any particular choice of plant parts for sampling in the field. Critical $\mathrm{N}$ concentrations recommended at anthesis are: $12 \mathrm{~g}$ of $\mathrm{N} \mathrm{kg}^{-1}$ in DM of the whole plant and $23 \mathrm{~g}$ of N kg${ }^{-1}$ in DM of the leaves (Peltonen 1992).

The amount of $\mathrm{N}$ to be applied when plants are deficient could not be measured in experiments by Siman (1974), Hagrove et al. (1983), Roth et al. (1989), Vaughan et al. (1990a) and Peltonen (1992). According to BHATIA and RABSON (1976), the relative increase in $\mathrm{N}$ required for protein production could be calculated by the system of SINCLAIR and de WIT (1975) on the basis of biochemical pathways derived by PENNING de VRIES et al. (1974). This system may provide an effective tool for calculating the supplemental $\mathrm{N}$ requirement of the crop if there is lack of $\mathrm{N}$ at certain developmental stages. VAUGHAN et al. (1990b) developed the multiple regression models to estimate $\mathrm{N}$ fertilizer requirement at various stages of growth. Nitrogen requirement can also be calculated with the concept of a balanced other nutrient composition of the plant by the diagnosis and recommendation integrated system (DRIS) methods (BEAUFILS 1973).

\section{Conclusions}

On the basis of grain protein concentration data, growers producing spring wheat with consistently low protein concentration are advised to pursue a more vigorous and better planned $\mathrm{N}$ fertilization programme in their crops. Analyzing previous research data to identify the 'critical level' of grain protein concentration is not difficult, and will provide growers, extension personnel, and fertilizer dealers with a cost-effective means of evaluating the efficiency of $\mathrm{N}$ use by the crop and for developing $\mathrm{N}$ fertilization recommendations based on those data. Information on the post-harvest grain protein concentration can easily be obtained by wheat growers because grain protein determinations are a routine part of its marketing.

The critical tissue $\mathrm{N}$ content could be an effective diagnostic tool for justifying the need of supplementary $\mathrm{N}$ fertilizer of a crop during the preharvest phase. The $\mathrm{NO}_{3}-\mathrm{N}$ tests have been reported to vary greatly from site to site, and can change rapidly over time. Therefore, more samples were needed to achieve a confidence level of accuracy for the $\mathrm{NO}_{3}-\mathrm{N}$ test than for testing the whole plant total $\mathrm{N}$ concentration. It is concluded that the observed differences between critical $\mathrm{N}$ levels could be due to the differences in the growing conditions in varying geographical regions and/or wheat classes. Nitrogen uptake (mg per plant) should be measured, because this information indentifies whether a high $\mathrm{N}$ concentration is due to low dry-mass production or high $\mathrm{N}$ uptake level of the wheat plant. There is requirement of rapid plant $\mathrm{N}$ analysis methods in the field or in the laboratory. When tissue $\mathrm{N}$ is determined in the laboratory, the analytical data could be supplemented by a recommendation of the amount of supplemental $\mathrm{N}$ fertilizer required to increase tissue $\mathrm{N}$ above the critical level. 


\section{References}

AlDRICH, S.R. 1973. Plant analysis: problems and opportunities. p. 213-221. In: Walsh, L.M. \& Beaton, J.D. (eds.). Soil testing and plant analysis. Soil Sci. Soc. of Amer., Inc. Madison, Wis.

ANGUS, J.F. \& MonCUR, M.W. 1985. Models of growth and development of wheat in relation to plant nitrogen. Aust. J. Agric. Res. 36: 537-544.

BEAUFILS, E.R. 1973. Diagnosis and recommendatioin integrated system (DRIS). Soil Sci. Bull. No. 1, Univ. of Natal, Pietermarizburg.

BENZIAN, B. \& LANE, P. 1981. Interrelationship between N concentration in grain, grain yield and added fertilizer nitrogen in wheat experiments of South-east England. J. Sci. Food Agric. 32: 35-43.

Beringer, V.H. \& Hess, G. 1979. Brauchbarkeit der Pflanzenanalyse zur Bemessung spater N-gaben zu Winterweizen. Landwirtsch. Forsch. 32: 384-394.

BhatiA, C.R. \& RABSON, R. 1976. Bio-energetic considerations in cereal breeding for protein improvement. Science 194: 1418-1421.

BREMNER, P.M. 1972. Accumulation of dry matter and nitrogen by grains in different positions of the wheat ear as influenced by shading and defoliation. Aust. J. Biol. Sci. 25: 657-668.

CAMPBell, C.A. \& READ, D.W. 1968. Influence of air temperature, light intensity and soil moisture on the growth, yield and some growth analysis characteristics of chinook wheat grown in the growth chamber. Can. J. Plant Sci. 48: 299-311.

Cate, R.B. \& Nelson, J.A. 1971. A simple statistical procedure for partitioning soil test correlation data into two classes. Soil Sci. Am. Proc. 35: 658-660.

Elonen, P., RinNe, S.L. \& SuOMELA, H. 1975. Influence of irrigation and nitrogen fertilization on grain yield and some baking quality characteristics of spring wheat. J. Scient. Agr. Finl. 47: 166-180.

ENGEL, R.E. \& ZUBRISKI, J.C. 1982. Nitrogen concentrations in spring wheat at several growth stages. Commun. Soil Sci. Plant Anal. 13: 531-534.

EsALA, M. 1991. Split application of nitrogen: effects on the protein in spring wheat and fate of ${ }^{15} \mathrm{~N}$-labelled nitrogen in the soil-plant system. Ann. Agric. Fenn. 30: 219-309.

FAJERSSON, F. 1961. En jämförelse mellan kalksalpeter- och ureagödsling till Svenno vårvete. Agri Hort. Gen. 19: 311-318.

Fowler, D.B. \& de la Roche, I.A. 1984. Winter wheat production on the north central Canadian Prairies: Protein quality classes. Crop Sci. 24: 873-876.

GARDNER, B.R. \& JACKSON, E.B. 1976. Fertilization, nutrient composition, and yield relationships in irrigated spring wheat. Agron. J. 68: 75-78.

Goos, R.J. 1984. Post-harvest evaluation of nitrogen management - a new approach for "selling soil testing to wheat farmers". J. Agron. Educ. 13: 103-106.

-, Westfall, D.G., Ludwick, A.E. \& Goris, J.E. 1982. Grain protein content as an indicator of $\mathrm{N}$ sufficiency for winter wheat. Agron. J. 74: 130-133.

Hagrove, W.L., Touchton, J.T. \& Johnson, J.W. 1983. Previous crop influence on fertilizer nitrogen requirements for double-cropped wheat. Agron. J. 75: 855-859.

HarPer, L.A., Sharpe, R.R., Langdale, G.W. \& Giddens, J.E. 1987. Nitrogen cycling in a wheat crop: soil, plant, and aerial nitrogen transport. Agron. J. 79: 965-973.

HEIKKILÄ, T. 1980. Typpilannoitteiden taloudellisesta käytőstä koetulosten perusteella. Agric. Econ. Res. Inst. Finl. Res. Report 70. 45 p.

Herzog, H. \& Stamp, P. 1983. Dry matter and nitrogen accumulation in grains at different ear position in 'gigas', semidwarf and normal spring wheats. Euphytica 32: 511-520.

JAAKKOLA, A. 1978. Nitrate, ammonium and urea nitrogen as fertilizers for wheat and rye in a field experiment. $\mathbf{J}$. Sci. Agric. Soc. Finl. 50: 346-360.

KonTtURI, M. 1979. The effect of water on yield and development of spring wheat in Finland. Ann. Agric. Fenn. 18: 263-274.

LANGE, E.C. 1954. Growth stages in cereals. Illustration of Feekes scale. Plant Path. 3: 128-129.

Lawlor, D.W., Kontturi, M. \& Young, A.T. 1989. Photosynthesis by flag leaves of wheat in relation to protein, ribulose bis-phosphate carboxylase activity and nitrogen supply. J. Exp. Botany 40: 43-52.

-, Boyle, F.A., Keys, A.J., Kendall, A.C. \& Young, A.T. 1988. Nitrate nutrition and temperature effects on wheat: a synthesis of plant growth and nitrogen uptake in relation to metabolic and physiological processes. J. Exp. Botany 39: 329-343.

Mikesell, M.E. \& Paulsen G.M. 1971. Nitrogen translocation and the role of individual leaves in protein accumulation in wheat grain. Crop Sci. 11: 919-922.

Møller Nielsen, J. \& Frils-Nielsen, B. 1976. Evaluation and control of the nutritional status of cereals. I. Dry matter weight level. Plant \& Soil 45: 317-338.

NeEdham, P. 1983. Nitrogen prediction and timing: A review of trials and advice. In: The Yield of Cereals. Proc. Intern. Seminar. R. Agric. Soc. England. Monograph Series No. 1. p. 69-75.

Nelson, L.A. \& Andersen, R.L. 1977. Partitioning of soil test crop response probability. p. 19-38. In: Peck, T.R. et al. (eds.). Soil Testing: Correlation and Interpreting the Analytical Results. ASA Spec. Publ. 29. ASA, Madison. WI.

NitSCH, A. \& VARIS, E. 1991. Nitrate estimates using the Nitrachek Test for precise $\mathrm{N}$-fertilization during plant growth and, after harvest, for quality testing potato tubers. Potato Research 34: 95-105. 
NoAman, M.M. \& TAYLOR, G.A. 1990. Vegetative protein and its relation to grain protein in high and low grain protein winter wheats. Euphytica 48: 1-8.

Papastylianou, I. 1984. Diagnosis of the nitrogen status of wheat at tillering and prognosis for maximal grain yield. Commun. Soil Sci. Plant Anal. 15: 1423-1436.

— \& PUCKRIDGE, D.W. 1981. Nitrogen nutrition of cereals in a short-term rotation. II Stem nitrate as an indicator of nitrogen availability. Aust. J. Agric. Res. 32: 713-723.

Peltonen, J. 1992. Tissue nitrogen as a base for recommendations of additional nitrogen to spring wheat in southern Finland. Acta Agric. Scand. 42: 164-169.

— \& KARJALAINEN, R. 1992. Effects of fungicide sprays on foliar diseases, yield, and quality of spring wheat in Finland. Can. J. Plant Sci. 72: 955-963.

-, Karvonen, T. \& Kivi, E. 1990. The effect of climatic factors of spring wheat quantity to quality ratio in southern Finland. J. Agric. Sci. Finl. 62: 227-236.

Penning de Vries, F.W.T., Brunstting, A.H.M. \& VanLAAR, H.H. 1974. Products, requirements and efficiency of biosynthesis: A quantitative approach. J. Theor. Biol. 45: 339-377.

RAININKO, K. 1966. Myöhäisen typpilannoituksen vaikutus kevätvehnän satoon ja leivinominaisuuksiin. J. Scient. Agric. Soc. Finl. 38: 140-149.

Roth, G.W., Fox, R.H. \& Marshall, H.G. 1989. Plant tissue tests for predicting nitrogen fertilizer requirements of winter wheat. Agron. J. 81: 502-507.

SCAIfE, A. \& Stevens, K.L. 1983. Monitoring sap nitrate in vegetable crops: Comparison of test strips with electrode methods, and effects of time of day and leaf position. Commun. Soil Sci. Plant Anal. 14: 761-771.

Scharpf, H.C. \& Wehrmann, J. 1976. Die Bedentung des Mineralis tickstoffrorrates des Bodes zu Vegetationsbeginn für die Bemessung des N-Düngung zu Winterweizen. Land Forsch. Sonderh. 32: 100-114.

Seth, J., Hebert, T.T. \& Middleton, G.K. 1960. Nitrogen utilization in high and low protein wheat varieties. Agron. J. 52: 207-209.

SIMAN, G. 1974. Nitrogen status in growing cereals with special attention to the use of plant analysis as a guide to supplemental fertilization. Diss. R. Agric. Coll. Sweden. $93 \mathrm{p}$.

Sinclair, T.R. \& de WiT, C.T. 1975. Photosynthate and nitrogen requirements for seed production by various crops. Science 189: 565-567.

SPIERTZ, J.H.J. 1977. The influence of temperature and light intensity on grain growth in relation to the carbohydrate and nitrogen economy of the wheat plant. Neth. J. Agric.
Sci. 25: 182-197.

— \& ElLEN, J. 1978. Effects of nitrogen on crop development and grain growth of winter wheat in relation to assimilation and utilization of assimilates and nutrients. Neth. J. Agric. Sci. 26: 210-231.

SPRATT, E.D. 1974. Effect of ammonium and nitrate forms of fertilizer- $\mathrm{N}$ and their time of application on utilization of $\mathrm{N}$ by wheat. Agron. J. 66: 57-61.

STANFORD, G. 1982. Assessment of soil nitrogen availability. In: Stevenson, F.J. (ed.). Agricultural Soils. Agronomy 22: 561-720.

STEENBJERG, F. 1951. Yield curves and chemical plant analysis. Plant \& Soil 3: 97-109.

Svensson, G. \& LindAhL, L. 1989. The influence of late fertilization with urea solution and calcium nitrate on baking quality in wheat. Agri Hort. Gen. 45: 25-32.

Ulrich, A. \& Hills, F.J. 1967. Principles and practices of plant analysis. p. 11-24. In: Soil testing and plant analysis. Part II. SSSA Special Publ. Series No. 2. Soil Sci. Soc. of Amer., Madison, Wis.

Vaughan, B., Barbarick, K.A., Westfall, D.G. \& ChapMAN, P.L. 1990a. Tissue nitrogen levels for dryland hard red winter wheat. Agron. J. 82: 561-565.

-, Westfall, D.G., Barbarick, K.A. \& Chapman, P.L. 1990b. Spring nitrogen fertilizer recommendation models for dryland hard red winter wheat. Agron. J. 82: 565-571.

Wehrmann, J. \& ScharPF, H.C. 1979. Der Mineralstickstoffgehalt des Bodes als Massstab für den Stickstoffdüngerbedarf $\left(\mathrm{N}_{\min }-\right.$ Methode). Plant \& Soil 52: 109-126.

-, Scharpf, H.C., Böhmer, M. \& Wollring, J. 1982. Determination of nitrogen requirements by nitrate analysis of the soil and of the plant. Plant Nutrition 1982. Proc. 9th Intern. Plant Nutrition Colloquium. Seite. p. 702-709.

Willey, R.W. \& Holliday, R. 1971. Plant population, shading and thinning studies in wheat. J. Agric. Sci. Camb. 77: 453-461.

Zadoks, J.C., Chang, T.T. \& KonZaK, C.F. 1974. A decimal code for the growth stages of cereals. Weed Res. 14: 415-421.

Manuscript received September 1992

Jari Peltonen

University of Helsinki

Department of Plant Production

SF-00710 Helsinki, Finland 


\title{
SELOSTUS
}

\section{Kasvianalyysit kevätvehnän typpilannoituksen tarkentamisessa}

\author{
JARI Peltonen
}

Helsingin yliopisto

Tämă kirjallisuustutkimus osoitti, että mikäli typpi on ollut rajoittava tekijä sadon muodostukselle, aiheuttaa se sekă alhaisen sadon että valkuaispitoisuuden (Kuva 1). Toisin sanoen, jos viljelijä tuottaa vehnäsadon jonka valkuaispitoisuus jăă alle kriittisen raja-arvon, tulisi hänen lisătä typpilannoituksen maaărăă viljelyă jatkaessaan. Menetelmăn soveltaminen käytăntöön on perusteltua, koska sadon valkuaispitoisuus kuuluu laatuhinnoitteluun.

Mikäli kasvien typen puute havaitaan riittävăn aikaisin, ennen năkyviä puutosoireita lehdistössä, täydennystyppeä voidaan lisätä ennen kuin satopotentiaali ja valkuaispitoisuus alentuvat. Nitraattityppeen perustuvat pikatestit ovat kuitenkin epäluotettavia. Sen sijaan nopea, kasvin kokonaistyppeä mittaava analyysi on typpilannoituksen optimoimiseen tarpeellinen. Kriittisiä typpiarvoja kasvin eri kehitysvaiheissa on esitetty taulukossa 1. Kasvianalyysin tulisi sisăltăă typpipitoisuuden lisăksi suositus mahdollisesta täydennystypen määrästä $(\mathrm{kg} / \mathrm{ha})$, joka tarvitaan kohottamaan kasvin typpipitoisuus kriittisen arvon yläpuolelle. 